\title{
Solar-Based Electric Vehicle Charging: Analysis of Conception and Regulation in Indonesia
}

\author{
Sunny Ummul Firdaus*, Muhamad Alief Hidayat, Anugrah Muhtarom Pratama, and \\ Khaisya Refaya Vidzal
}

Pusat Studi Demokrasi dan Ketahanan Nasional Universitas Sebelas Maret ${ }^{*}$ Corresponding author. Email: firdaussunny@staff.uns.ac.id

\begin{abstract}
This research aims to elaborate on the problem of increasing air pollution due to motor vehicle exhaust emissions in Indonesia. These exhaust emissions are caused by the use of fossil fuels, where the majority of motor vehicles used are still conventional. This problem gives rise to the innovation of electric vehicles as one of the efforts to reduce air pollution that occurs. However, in its course, electric vehicle power sources still use electric power generated from processed fossil materials. Of course, it becomes useless if the procurement of electric vehicles also affects increasing the exploitation of non-renewable energy sources. The existence of solar power that is very abundant in Indonesia can undoubtedly be a means of fulfilling power in electric vehicles. In this study, the authors used socio-legal research methods. The final result of this study is a study on legal guarantees on electric vehicles in Indonesia, the ideal concept of using solar power as a renewable resource in charging electric vehicles, and recommendations to the government to apply the ideal concept to achieve national acceleration.
\end{abstract}

Keywords: Electric Vehicle, Solar, Emissions Gas

\section{INTRODUCTION}

Air pollution is a condition in which the raw quality of air becomes damaged and contaminated by certain substances that directly affect the composition of existing air. According to chambers and masters, air pollution is the increase of physical or chemical materials or substrates into a normal air environment that reaches a certain amount so that it can be detected by humans (or can be calculated and measured) and can have effects on humans, animals, vegetation and materials [1]. Air pollution is undoubtedly caused by various factors, including the disposal of emission gases, the existence of industrialized air waste, and so on. The high number of air pollution is also directly proportional to the increasing intensity of modernization life, such as high community mobility, increasingly mushrooming industrialization, and the increasing use of private motor vehicles due to their effectiveness and efficiency. The primary source of air pollution is from transportation, especially motor vehicles. The resulting pollution consists of $60 \%$ carbon monoxide, and about $15 \%$ consists of hydrocarbons, lead [2].

Exhaust emissions of motor vehicles are one of the problems that continue to roll and are faced not only in
Indonesia but also globally. WHO data shows that $92 \%$ of the world population are exposed to PM 2.5 air pollution concentrations that are above the annual mean WHO AQG levels of $10 \mu \mathrm{g} / \mathrm{m} 3$ (World Health Organization, 2016). One of the efforts sought to overcome this problem is the existence of electric vehicle technology that is projected not to produce exhaust emissions due to fossil fuels and uses electric battery technology. Indonesia is currently also contributing to the government's policy in terms of procurement and production of electric vehicles that continue to be launched. But one of the things that have not been noticed by the government, in this case, is the use of fossil power in Indonesia's electricity production, which will certainly aggravate the situation if electric vehicles can be applied properly and massively by the community. The increase in the use of electric vehicles certainly requires a large power source and has direct implications for the exploitation of fossil power, a non-renewable resource. The potential existence of solar cells as Indonesia's largest renewable power source shows that Indonesia is passed by the solar line that provides extensive solar irradiation to be utilized as a renewable power source for electric charging. However, the reality until now, the use of solar power is still very little implemented and tends 
not to be appropriately utilized by the people of Indonesia in various ways.

With the background above, the author will raise the discussion point about the urgency of utilization and regulation of the use of solar power as a renewable power source for electric vehicles in Indonesia. Then continued about the ideal concept of the use of solar energy as a renewable power source of electric vehicles in Indonesia. In this study, the authors use socio-legal research methods, where the study of the law is based on the development of society in various segments of life.

\section{DISCUSSION}

\subsection{The Urgency of Utilization and Regulation of the Use of Solar Power as a Renewable Power Source of Electric Vehicles in Indonesia}

The existence of transportation technology in the form of electric vehicles is currently one of the modern renewable projections as one of the solutions to the increase in air pollution globally. The advantages of electric vehicles (EVs) over ICE/ICEV (Internal Combustion Engine Vehicle) include not being noisy, high energy conversion efficiency, reducing the use of fuel oil to reduce exhaust gases into the atmosphere directly, and gas emissions that are centralized so that it is more manageable [3]. This advantage is one of the essential things to apply immediately, especially with the air quality that is currently at an alarming level.

Air pollution concentrations in Indonesia ranked sixth highest in the world with a score of 51.7, and DKI Jakarta as the 5th city in the world with the highest concentration of air pollution with a score of 49.4. The city's rapid growth has coincided with heightened PM2.5 levels, as the growing population adds to its notorious traffic congestion and coal-based energy demand. Since 2017, PM2.5 levels in the city have increased by $66 \%$ [4]. Jakarta suffered an estimated 13,000 avoidable deaths due to PM2.5 air pollution in 2020 and sustained air pollutionrelated losses of USD 3.4 billion, equivalent to $8.2 \%$ of the city's total GDP [5], so $91 \%$ of Indonesia's population lives in areas with air pollution levels exceeding safe limits set by the World Health Organization (WHO) [6].

The existence of electric vehicles is also directly related to efforts to reduce exhaust emissions are still high in Indonesia. As a country with considerable fossil energy use, Indonesia produced 1,637,156 million tons of GHG emissions in 2018 [7]. This number places Indonesia at the mid-table of the world's largest emitters [8]. This increase in emissions is increasingly alarming, considering that it is directly proportional to the increase in the number of conventional vehicles in Indonesia today. Data from the Central Statistics Agency in 2019 showed that in 2019, the number of vehicles increased by $7,108,236$ units or increased 5.3 percent to $133,617,012$ units from the previous year of $126,508,776$ units [9] where the passenger car accounted for 11.6 percent of the total vehicles in Indonesia with a total of 15,592,419 units. While the largest contributor to the number of vehicles is motorcycles, which in 2019 number reached 112,771,136 units greater than the number in the previous year, which only reached 106,657,952 units.

The public's concern about the impact of gas emissions and air pollution underlies the production and industrialization in the field of procurement of electric motor vehicles by the government and various other parties who race to create battery-based electric vehicles. Various current policies and regulations have provided guarantees for implementing electric vehicles in Indonesia, ranging from design to use. This is seen with the Presidential Regulation No. 55 of 2019 on Accelerating the Battery Electric Vehicle (BEV) Program for Road Transportation. This regulation provides direction, foundation, and legal certainty for the existence of BEVs and encourages the mastery of industrial technology and the design of electric vehicles. The things regulated in this regulation are the acceleration of the development of the domestic BEV industry in the form of setting the stage of industrial company establishment, research and development of BEV industry innovation, determination of BEV components, and control of the use of fossil fuel vehicles. In addition, this regulation also regulates the provision of incentives, both fiscal and nonfiscal, the provision of electric charging infrastructure or electric vehicle charging stations and the regulation of electric power tariffs for BEVs, technical provisions for the implementation of $\mathrm{BEVs}$ ranging from registration of vehicle numbers, operating requirements, and identification of $\mathrm{BEVs}$, and protection of the environment. Another regulation is the coordination of $\mathrm{BEV}$ implementation by the coordination team held by the Maritime Ministry assisted by other ministries concerned.

Other regulations of $\mathrm{BEV}$ are also regulated in the Regulation of the Minister of Energy and Mineral Resources No.13 of 2020 on the provision of electric charging infrastructure for BEVs. The things stipulated in this regulation are BEV electric charging infrastructure with the existence of recharging facilities in the form of electric power supply equipment, current control system, voltage and protection and safety system, the existence of private electricity installation and public electric vehicle charging stations that are directly related to the determination of the business scheme of authorized business entities in charging stations. Furthermore, there is also a charging electricity tariff for BEV with regard to electricity tariffs on business entities, the safety of electricity infrastructure electric charging $\mathrm{BEV}$ in the form of obligations that must be fulfilled on battery charging, coaching and supervision by the directorgeneral of private electricity installation owners, business entities of electric charging stations. Administrative sanctions are also regulated in this regulation for violations committed by the owner of the electric charging station installation and violations by other parties by establishing written reprimands, freezing activities, and 
revocation of business licenses or revocation of business entity identity numbers.

Further regulations certainly accompany the existence of Presidential Regulation No.55 of 2019 as part of BEV regulation. The follow-up regulations include the Regulation of the Minister of Industry No.27 of 2020 on specifications, development roadmaps, and provisions for calculating the value of domestic component levels of BEV and Regulation of the Minister of Industry No.28 of 2020 on the existence of battery-based electric motor vehicles in a state of complete unraveling and incomplete decomposing. The matters stipulated in the Regulation of the Minister of Industry No.27 of 2020 include the arrangement of the production and procurement process of motor vehicles in the early stages in the form of determining the number of component levels to be used until the use and launch of BEVs, the development of the BEV industry in 2020-2030, the coordination of implementation between ministries, research institutions and related institutions, local governments and universities.

While the things stipulated in the Regulation of the Minister of Industry No.28 of 2020 are regarding completely knockdown (CKD) or incompletely knockdown (IKD) based $\mathrm{BEV}$ in determining the components to be used, companies involved in the manufacturing and production process of BEV. In addition, the regulation also regulates the implementation of four-wheeled BEV importation based on a letter of approval issued by the director-general. This regulation also regulates the reporting and supervision functions owned by the director-general through the socialization of the national industry information system (SIINas) regarding violations committed.

The above regulations explain that BEVs in Indonesia have been guaranteed by law and received the direct delegation in Indonesian laws and regulations. In the course, there are still things that have not been regulated about the technical use of BEVs, such as the use of fossilbased electric power in charging the electric vehicle's battery. This is a problem related to the goal of reducing the use of non-renewable energy sources to maintain quality and environmental sustainability. It becomes useless if BEV can be appropriately applied, but the electricity resources used in it are still based on fossil power which, if the amount and capacity of BEV in Indonesia are very much will certainly have direct implications for the process of processing mining resources into high electricity as well. Indonesia has also built an electric vehicle battery factory established by Hyundai Motor Group and LG Energy Solution. Furthermore, the resources used in charging BEV are still not clearly regulated regarding the use of renewable energy resources.

If further reviewed, this should get a clear regulation on using renewable energy resources further using natural power plants, one of which is solar power. Until now, regulations regarding the use of solar power in public
BEV charging systems have not been rolled out by the government either through policies or regulations. Solar power is the most potential source of electricity in Indonesia, where the radiation intensity is higher than other regions of $4.66-5.54 \mathrm{kWh} / \mathrm{m}^{2}$ per day. This is among the best to be used as PLTS (Solar Power Plant) [10]. Furthermore, the western and eastern regions of Indonesia with the distribution of irradiation in the Western Region of Indonesia (KBI) around 4.5 $\mathrm{kWh} / \mathrm{m}^{2} /$ day with a monthly variation of about $10 \%$; and in the Eastern Region of Indonesia (KTI), about 5.1 $\mathrm{kWh} / \mathrm{m}^{2} /$ day with a monthly variation of about $9 \%$ [11]. The existence of abundant solar power is what needs to be utilized in the use of BEV.

Guaranteeing regulations regarding the use of solar power is vital to encourage the community's need, BEV industry companies, and related institutions to accommodate solar power as a battery source for electric vehicles. The synergy between the procurement of BEV and charging BEV using solar power is what will encourage the maximum reduction of the use of fossil power, where until now, fossil power has been widely used as a vehicle fuel and Indonesia's electricity source so that the use of solar power will certainly have direct implications for the acceleration of the use of BEV and the reduction of air pollution that occurs until now.

\subsection{Ideal Concept of Utilization of Solar Energy as a Renewable Resource of Electric Vehicles in Indonesia}

\subsubsection{Use of Solar Energy Electricity in Indonesia}

Energy use in Indonesia, for now, is still very dependent on power plants dominated by fossil energy, especially coal through power generation. This consumption is seen from the amount of coal use in Indonesia which is still very high by $63.92 \%$ [12]. Because coal consumption is still high, there are concerns about the availability of coal sources themselves, considering that coal is currently increasingly limited and has environmental impacts that provide a threat to climate change. These concerns are coupled with future needs, where growth and an increase in the proportion of electricity consumption will increase [13]. One of the reasons for the increase in electricity consumption is the emergence of the use of electric vehicles in the future, where it takes a source of electricity from clean energy to still ensure a guaranteed environment.

In facing and overcoming these challenges, Indonesia, which is ranked 33rd in the world in electricity consumption, needs to do utilization solutions using renewable energy. The use of renewable energy is a solution because it is intended to alleviate concerns of climate change and pollution from the utilization of fossil energy electricity [14]. One that has the potential to be used in Indonesia is solar energy. Solar energy is a good 
choice because Indonesia has an enormous solar power generation potential of $207.8 \mathrm{GW}$ [15].

The use of solar energy today has also become very strategic despite the Covid-19 pandemic. In fact, global trends in recent decades have led many countries to increase solar energy development. In 2017 alone, the installation of solar power plants has contributed more than the capacity of nuclear and fossil energy plants [16]. Factors such as falling prices and the cost of installing more competitive solar energy make future solar energy even more promising [17]. The international energy agency (IEA) has also stated that 'solar is a new king' will be a major driver in the future growth of renewable energy [18]. Not only that, based on projections by The International Renewable Energy Agency (IRENA), there will be an exponential explosion caused by the production and installation of solar panels in the future so that it will open new jobs for the community and diversify the business for fossil energy companies [19]. Based on the IRENA study, the production and installation of solar panels will contribute to increasing employment from 100.000 to 1.3 million by 2030 [19]. In Indonesia, the use of solar energy itself is an ambitious target of the government by 2050 , where solar energy is the most significant contributor to the utilization of renewable energy (see Figure 1 in yellow).

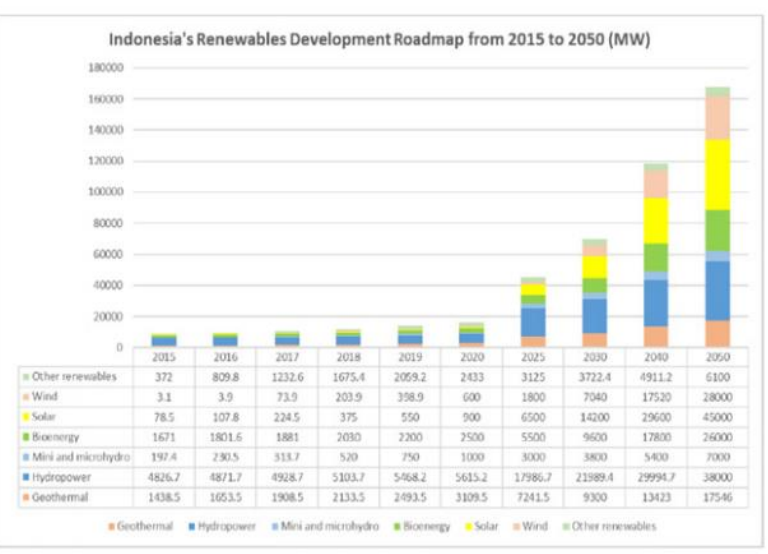

Figure 1. Source: IESR (2018)

However, the development and utilization of solar energy in Indonesia, for now, is still very low, with 153.3 MW. The problem is that the price is still high and can not compete compared to the price of fossil energy. Please note that the price of electricity from solar energy in Indonesia is currently still 5.72 cents USD / kWh which is different from the price of electricity from fossil energy of 3 cents USD / $\mathrm{kWh}$. In addition to the price that is still expensive, actors between the Ministry of Energi (ESDM) and PLN are also still not in line. The ESDM ministry is interested in developing solar energy on a full scale to achieve energy security and reduce carbon emissions. However, PLN is hampering the pace of solar energy development and encouraging the continuation of dependence on coal as a source of electricity that has currently invested large amounts and is experiencing oversupply [20]. As a result, without a set of policies and support that are in line, the transition process in the development of solar energy becomes slow. This evidence is seen with the comparison of solar energy utilization among ASEAN countries (see Figure 2).

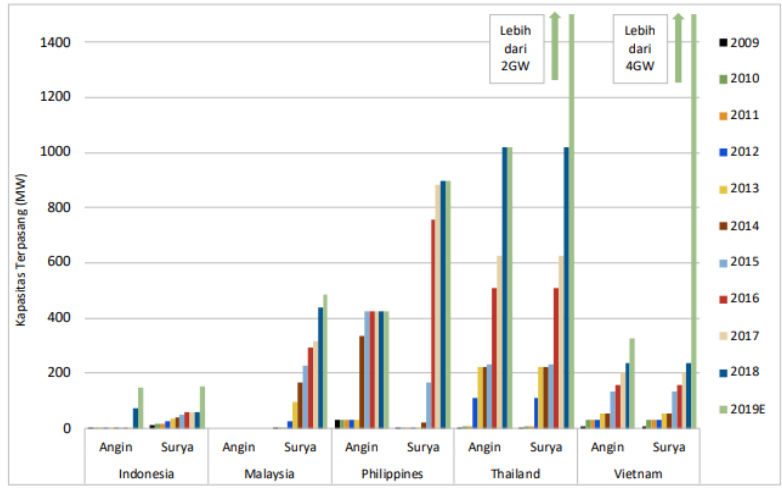

Figure 2. Source: IRENA (2019)

The development and utilization of solar energy will provide a sustainable multiplier effect for Indonesia. Especially with the conditions of the Covid-19 pandemic that require economic recovery, the development of solar energy becomes a weapon to support this program. This is in line with research conducted by Oxford University Economic Recovery Project, that green energy investment is the key to post-pandemic economic recovery because it will bring long-term environmental benefits without neglecting the short-term economic value [21]. Not to mention Indonesia, which wants to become an electric vehicle market so that solar energy utilization will support its existence in achieving the target of the Paris agreement.

Looking at the explanations above, a strategy is needed for how solar energy can reduce fossil fuels in support of electric fueling in Indonesia. In doing so, the authors introduced the concept of a solar park that could later help supply electricity as clean energy so that solar energy is increasingly used and the price of solar energy can compete with fossil energy while achieving the government's ambitious targets in the Paris agreement. This is also compared to the strategies implemented in India. The choice of India is because it is a developing country and has geographical, economic, socio-cultural circumstances to dependence on coal similar to Indonesia. This article begins by describing India's largest renewable energy contributor derived from solar energy using large-scale solar park development strategies, including rooftop installations powered by reverse auction mechanisms. The next part explains the concept of the Nusantara solar park in the form of largescale PLTS both on the land and floating by maximizing the reverse auction mechanism that needs to be maximized in the Renewable Energy Draft Law (Draft Law EBT). 


\subsubsection{India's Solar Park: An Important Lesson for Indonesia}

India has great potential and seeks to harness several renewable energy sources, including solar, wind, bioenergy, and water energy. The burgeoning local industry for manufacturing renewable energy technologies, especially solar energy, has significantly impacted the development and helped enforce renewable energy targets in India [22]. In 2010, India's Ministry of New and Renewable Energy created the Jawaharlal Nehru National Solar Mission (JNNSM) with the aim of building $20 \mathrm{GW}$ of solar energy by 2022 . Under JNNSM, India established the Solar Energy Corporation of India (SECI) in 2011. SECI is tasked with various initiatives to promote solar energy, including procurement. In the early phases, the approach used to drive solar energy in India was to use the Feed-in Tariff. Following strong interest from project developers, India then adopted a reverse auction mechanism in 2014. Reverse auctions involve industry players bidding for long-term PPA contracts with the lowest bids selected [22].

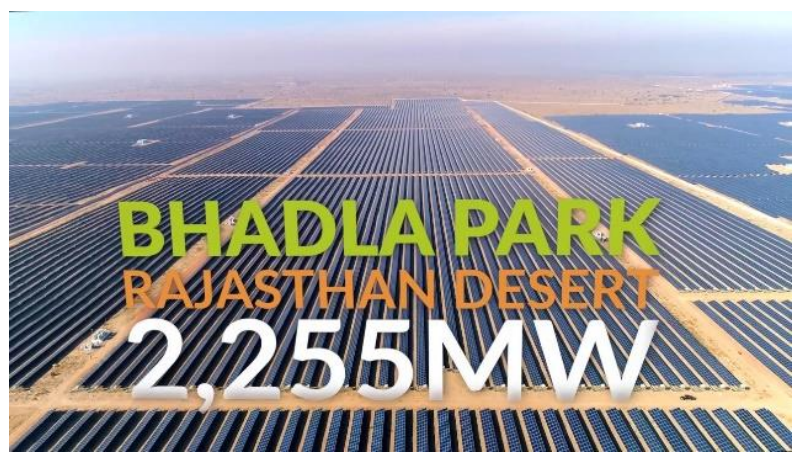

Figure 3. Bhadla Solar Park India: The largest solar park in the world. Source: Asia Record Institute (2020)

India's reverse auctions for solar power plants have shown intense competition and tremendous price declines (See Figure 4). India has established one of the most competitive solar energy markets and has some of the largest solar power plants in the world [23]. The main strategy is establishing a large-scale solar park led by the government carried out on the ground supported by an reverse auction mechanism [24]. To date, India has reached almost twice the specified target where installed capacity currently stands at $41.6 \mathrm{GW}$ by having more than 30 solar parks in operation [25]. India has now started designing the solar park for electric vehicle charging systems regarding charging electric vehicles through solar energy [26]. Solar gardens were chosen because the price offered is cheaper than applying roofbased. The distribution is done from a solar park that is converted to a grid of power plants.

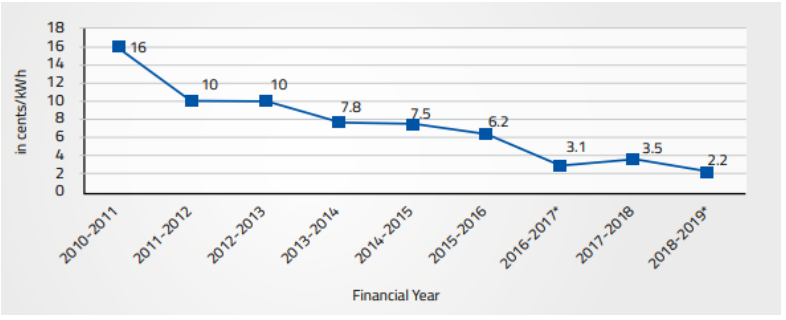

Figure 4. Source: IESR (2019)

There are some critical lessons for Indonesia if we want to implement a solar park that can be taken from India. India's success was the construction of large-scale solar parks using reverse auctions to secure low-price contracts in solar energy plants. Then, there is a special body as a significant key player in supporting solar energy development in India. These bodies that can increase transparency in its administration include managing funds and opening procurement as much as possible to attract investors.

\subsubsection{Nusantara Solar Park: Renewable Energy Acceleration Strategy for EV Charging in the Future}

Indonesia is committed to reducing emissions by $21 \%$ to $49 \%$ by 2030 . The commitment was then ratified in Law No. 16 of 2016 and realized in Presidential Regulation No. 22 of 2017 on the National Energy General Plan (RUEN) that Indonesia targets a new and renewable energy mix of $23 \%$ in 2025 and will increase to $31 \%$ in 2050 . Regarding solar energy, Indonesia in RUEN has committed to increasing solar energy capacity by $6.5 \mathrm{GW}$ in 2025 and $45 \mathrm{GW}$ in 2050 . Unfortunately, the ambitious target is not in line with current reality because it has not been followed by strategies and policies that support the acceleration of solar energy development and utilization. A crucial inhibitory factor is a price that is still expensive and has not competed with the price of fossil energy [27]. Although the development of solar energy prices in Indonesia has fallen every year, the current price of 5.72 cents USD/kWh is still much higher than other countries whose prices range from 1.042.2 cents USD/kWh. The authors initiated a Nusantara solar park inspired by Indian solar parks in the run-up to competing prices. In addition, the construction of the Nusantara solar park was chosen because, not without reason, the construction of the Nusantara solar park is the answer to combat the price of fossil energy so that one of them can be used in charging electric vehicles.

Nusantara solar park is the development and utilization of solar energy scattered in Indonesia by forming a park installed on the land and floating. For land can be selected, for example, in tolls and former mining land, while floating can be installed in the reservoir. Next, in supporting the construction of the Nusantara solar park, the use of reverse auctions will potentially provide a considerable boost for Indonesia [28]. The reverse auction method was chosen because it has been proven in India and other countries to push the price of 
solar energy to get lower[29]. A reverse auction mechanism quickly replaces the Feed-in-Tariff (FIT) mechanism to find the lowest rate. As a result, many countries worldwide have successfully conducted reverse auctions that result in the rapid addition of renewable energy generation capacity while finding the lowest prices. In India, it has abandoned the FIT mechanism and adopted a reverse auction mechanism to allocate renewable energy capacity [30]. In Brazil, reverse auctions helped lower the average price of solar auctions from 8.8 cents USD/kWh in 2014 to 1.75 cents $/ \mathrm{kWh}$ in 2019, down $80 \%$ in five years. In Mexico, solar energy prices decreased $54 \%$ from 4.49 cents USD/kWh in 2016 to 2.06 cents USD/kWh in 2017 [31]. China, Chile, Portugal, the United Arab Emirates have switched to reverse auctions [31]. Currently, Germany and Vietnam, which previously used FIT and bear higher prices, choose to change by conducting reverse auctions to get a better market price [31].

A reverse auction mechanism is designed where buyers (PLN and other stakeholders) give announcements about auctions containing explanations and requirements. Reverse auctions allow prices to be set through a competitive bidding process and provide an approach to create a more dynamic market as sellers (industry players) will submit proposals to buyers. Competition between sellers will cause a decrease in prices. Finally, based on several factors, the winner of the auction is chosen by the buyer. The price here is not just a reference but one of the factors for the final election. Buyers will still be researching to make sure the sellers meet the minimum eligibility requirements [32]. With the reversed auction mechanism, there will be no more pull of negotiations that become long. All competitors will offer competitive prices according to the market price index, which will be lower in price.

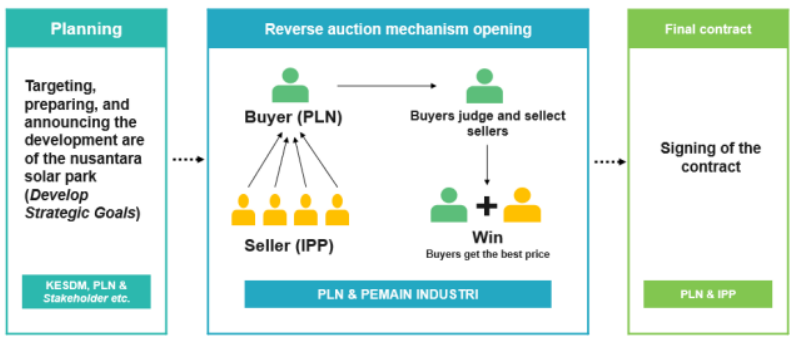

Figure 5. Concept of Reverse Auction Mechanism in the Construction of Nusantara Solar Park

Seeing this, there is also a strong policy push through legal products. Solar energy regulation in Indonesia has existed but has not discussed its construction using a reverse auction mechanism. In line with the existence of law, that the law aims as a means of community development, then the law is directed and empowered to be the main driver in development according to the will of the community, which is considered absolute and necessary for now [33]. In this theory, development is carried out by forming legislation through a legislative process that is currently considered necessary in the development agendas [34]. What people expect today is a desire to transition from fossil energy to renewable energy. To encourage the transition, renewable energy prices must be able to compete with fossil energy in order to be widely used.

In line with the explanation above, it clearly shows that large-scale PLTS with Nusantara solar parks will accelerate the decline in prices supported by reverse auction mechanisms. The accommodation of the reverse auction mechanism can currently be regulated in the EBT Draft Law that is being discussed by the House of Representatives and the Government. In the EBT Draft Law, the reverse auction mechanism has been included in Article 51 paragraph (2). Nevertheless, the reverse auction mechanism is still juxtaposed with the Feed-in Tariff (FIT). Article 51 paragraph (2) stipulated that determining the price of renewable energy can be done in the form of Feed-in Tariff, biofuel market index price, and/or reverse auction mechanism. In this case, there is something to look at. First, Article 40 paragraph (1) states that state electricity companies are obliged to buy electricity generated from renewable energy. The problem is that when the price produced by private companies to PLN is still expensive due to FIT, inevitably, PLN has to buy it. This needs serious attention. If PLN buys at a high price, then PLN and the STATE BUDGET must pay compensation for the difference in price in accordance with the provisions of Article 51 paragraph (4). As a result, the financial condition of both PLN and the country will be disrupted. It can result in chaos that compensation to pay for the shortage can be used to develop renewable energy. Therefore, the decline in the price of renewable energy needs to be done as soon as possible. One of them is the construction of a large-scale Nusantara solar park that uses an reversed auction mechanism.

This needs to be revisited regarding FIT. FIT in the EBT Draft Law needs to be limited because it will not reach competitive prices in the long run. FIT, in the long term, is difficult to achieve competitive prices because it lacks competitiveness. There are market-sided policies such as transparent and competitive auction mechanisms that can be achieved through reverse auction mechanisms because they are key to the future growth of renewable energy that has been developed from many countries. [29]. Although FIT can indeed be done in the beginning, but in this case, the government will work twice so that it becomes less efficient because it will prepare FIT arrangements and reverse auction mechanisms. In addition, there is a risk that if the transition from FIT to the reverse auction mechanism is not appropriate or running slowly, it can harm PLN's finances, including state finances. Therefore, in the EBT Draft Law, FIT must be affirmed for when it expires or only for certain types of technology on a small scale. This is not an excuse, as FIT, in the long run, is difficult to achieve competitive prices. The following reason is the current global trend heading towards reverse auction mechanisms for renewable energy projects. Many 
countries are already switching because the reverse auction mechanism makes prices more competitive [35].

Related to the reverse auction mechanism, after being included in the EBT Draft Law, then it needs to be accommodated in the regulations below to regulate technically the construction of the Nusantara solar park using a reversed auction mechanism. It is expected that with a set of regulatory policies that support the development of solar energy in Indonesia, the cultivation of solar energy for electricity in the future is very large. Later, the availability of electricity from solar energy can be used to charge electric vehicles in the future. The construction for charging electric vehicles is done by transferring solar energy to the grid that PLN already has through conversion. After converting solar energy to electricity through the PLN grid, integration is made that connects to homes and electric vehicle charging stations. This option is ideal with the aim that the price of solar energy in Indonesia can compete. By competing for electricity prices from fossil energy, it will be sustainably used by many people. The ideal concept of the author can be seen in the Figure below.

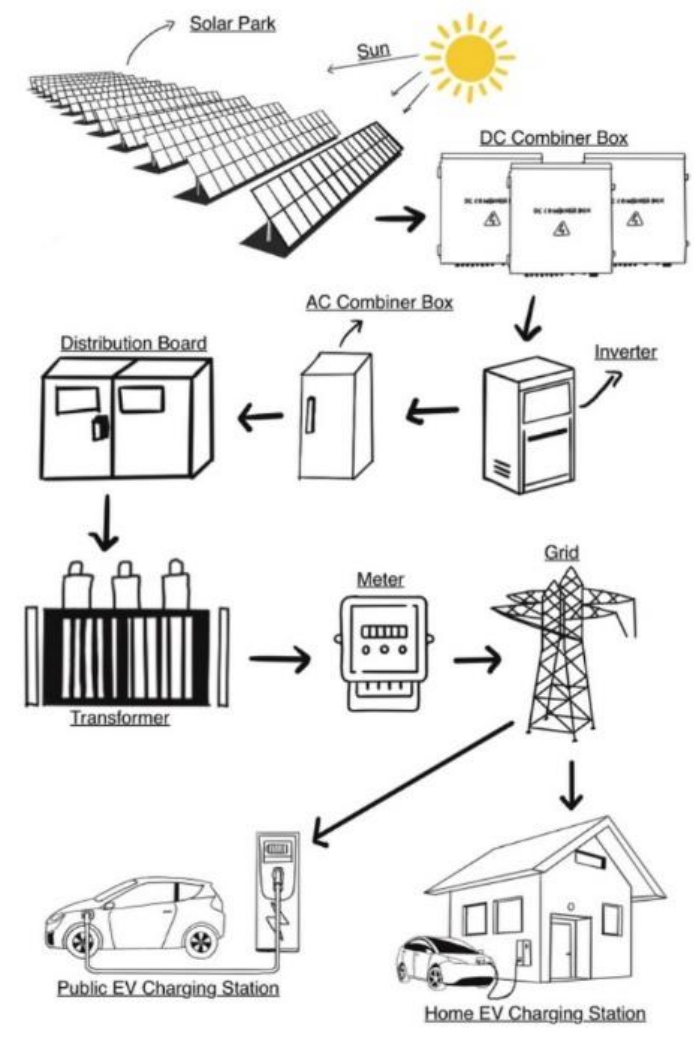

Figure 6. Nusantara Solar Park Concept for EV Charging in the Future

Furthermore, the above major steps also need to be supported by PLN to reduce the construction of power plants (PLTU) and review the power plant construction project to be stopped. The option that must be done at this time is to encourage the replacement of power plants with new and renewable energy plants, one of which is solar energy through the Nusantara solar park. It must be realized that the construction of the Nusantara solar park will provide many benefits. First, the opening of jobs that can be synchronized with the Pre-employment Card. In the Pre-employment Card, skilled labor can be created through education and training regarding solar energy installations. Furthermore, the government can absorb directly by opening vacancies through the construction of the Nusantara solar park. Second, the existence of rooftop PLTS can reduce electricity subsidies by 650 billion to 1.3 trillion/year (assuming development of $500 \mathrm{MW}-1$ GW) and carbon emissions by 1.14-2.28 tons/year (construction assumptions of 1-2 GW per year) [36]. Third, create national energy security. Fourth, prepare the electric vehicle ecosystem in the future. Lastly, the authors recommend appointing a specialized agency in the development of solar energy as in India. The appointment can be made by forming a new or existing body, namely the Environmental Fund Management Agency (BPDLH). The agency was formed with the aim to promote the development of renewable energy especially solar energy; managing the procurement of renewable energy, including reverse auctions; collecting, managing, and distributing funds; provision of data, research, and development; ensuring and implementing open access to equality in auctions; and increase transparency and investor attractiveness.

\section{CONCLUSION}

The Indonesian government has well-regulated regulations and policies regarding $\mathrm{BEVs}$, but in the run of important points in the use of electric vehicles have not been clearly regulated, causing the use of electricity until now still using fossil power as the primary source of electricity, especially in the EV charging process. This is certainly not in accordance with the goal to reduce the use of non-renewable energy resources in Indonesia. To that end, the authors offered the concept of solar parks that are expected to reduce electricity use from fossil energy. To implement a solar park, a reversed auction mechanism is used to compete with the price of fossil energy. Furthermore, the construction of the Nusantara solar park is channeled to the PLN grid and channeled both in public charging electric vehicles and at home.

\section{AUTHORS' CONTRIBUTIONS}

In creating this article, all authors contribute to the study of law on various literature, sociological conditions of the state, and comparative studies with the policies of other countries. So that all authors contribute actively to the preparation of this article.

\section{REFERENCES}

[1] B. Oktora, "Hubungan Antara Kualitas Fisik Udara Dalam Ruang (Suhu dan Kelembababn) Relatif) dengan Kejadian Sick Building Syndrome (SBS) pada Pegawai Kantor Pusat Pusahaan Jasa 
Konstruksi X di Jakarta Timur Tahun 2008," Universitas Indonesia, 2008.

[2] S. Fardiaz, Polusi Air dan Udara. Yogyakarta: Kanisius, 1992.

[3] N. S. Kumara and I. W. Sukerayasa, "Tinjauan Perkembangan Kendaraan Listrik Dunia Hingga Sekarang," Teknol. Elektro, vol. 8, no. 1, pp. 75, 2009.

[4] IQAir, "World Air Quality Report : Region \& City PM2.5 Ranking," 2019.

[5] Greenpeace Southeast Asia, "PM2.5 air pollution behind an estimated 160,000 deaths in world's 5 biggest cities in 2020," Greenpeace.org, 2021. https://www.greenpeace.org/southeastasia/press/44 319/pm2-5-air-pollution-behind-an-estimated160000-deaths-in-world-5-biggest-cities-in-2020/ (accessed Sep. 27, 2021).

[6] H. D. Situmorang, "Kualitas Udara di Indonesia Terus Memburuk," Berita Satu, 2021. https://www.beritasatu.com/nasional/783001/kualit as-udara-di-indonesia-terus-memburuk (accessed Sep. 25, 2021).

[7] Direktorat Jenderal Pengendalian Perubahan Iklim, "Laporan Inventarisasi Gas Rumah Kaca dan Monitoring, Pelaporan, dan Verifikasi 2020," Jakarta, 2020.

[8] A. I. Nur and A. D. Kurniawan, "Proyeksi Masa Depan Kendaraan Listrik di Indonesia: Analisis Perspektif Regulasi dan Pengendalian Dampak Perubahan Iklim yang Berkelanjutan," J. Huk. Lingkung. Indones., vol. 7, no. 2, pp. 199, 2021.

[9] Gaikindo, "Hasil Sensus BPS: Jumlah Kendaraan Bermotor di Indonesia Tembus 133 Juta Unit," gaikindo.or.id, 2021. https://www.gaikindo.or.id/data-bps-jumlahkendaraan-bermotor-di-indonesia-tembus-133juta-unit/ (accessed Sep. 27, 2021).

[10] I. A. Kurniawan, "Analisa Potensi Pembangkit Listrik Tenaga Surya (PLTS) Sebagai Pemanfaatan Lahan Pembangkit Listrik Tenaga Uap (PLTU) Paiton,” Institut Teknologi Surabaya, 2016.

[11] G. Widayana, "Pemanfaatan Energi Surya," $J$. Pendidik. Teknol. dan Kejuru., vol. 9, no. 1, pp. 39, 2012.

[12] Kementerian Energi dan Sumber Daya Mineral Republik Indonesia, Handbook of Energy and Economic Statistics of Indonesia 2020. Jakarta: Kementerian Energi dan Sumber Daya Mineral Republik Indonesia, 2021.

[13] D. Gielen, et al, "The Role of Renewable Energy in the Global Energy Transformation," Energy Strateg. Rev., vol. 24, pp. 38, 2019.

[14] J. A. Domínguez-Navarro, et al, "Design of an
Electric Vehicle Fast-charging Station With Integration of Renewable Energy and Storage Systems," Electr. Power Energy Syst., vol. 105, pp. 46, 2019.

[15] Richard Bridle, et al, "Missing the 23 Per Cent Target: Roadblocks to the Development of Renewable Energy in Indonesia," 2018.

[16] Frankfurt School-UNEPCentre/BNEF, "Global Trends in Renewable Energy Investment 2018,' 2018.

[17] Global Newswire, "Solar Energy Market-Growth, Trends, COVID-19 Impact, and Forecast (20212026)," 2021.

https://www.globenewswire.com/newsrelase/2021/06/16/2247951/0/en/solar-energymarket-growth-trends-covid-19-impact-andforecast-2021-2026.html (accessed Sep. 23, 2021).

[18] L. Stoker, "IEA: Solar the 'New King', Will Break Records for Decades to Come," PV Tech, 2020. https://www.pv-tech.org/iea-solar-the-new-kingof-power-will-break-records-for-decades-to-come/ (accessed Sep. 22, 2021).

[19] V. Tachev, "Renewable Energy in IndonesiaCurent State, Opportunities and Challenges," Energy Tracker Asia, 2021. https://energytracker.asia/renewable-energyindonesia/ (accessed Sep. 22, 2021).

[20] Akhmad Hidayanto, et. Al, "Investigating Policies on Improving Household Rooftop Photovoltaics Adoption in Indonesia," Renew. Energy, vol. 156, pp. 731-742, 2020.

[21] Medrilzam and H. Mountford, "A Low-Carbon Recovery Can Create Jobs and Boost Indonesia's Economy," WRI Indonesia, 2020. htpps://wriindonesia.org/en/blog/low-carbon-recovery-cancreate-jobs-and-boost-indonesia's-economy (accessed Sep. 23, 2021).

[22] R. Karim, F. Ghazali, and A.B. Ansari, "Renewable Energy Regulations in Indonesia and India: A Comparative Study on Legal Framework," J. Indones. Leg. Stud., vol. 5, no. 2, pp. 361-390, 2020.

[23] G. Shrimali, C. Konda, A.A. Farooquee“Designing Renewable Energy Auctions for India: Managing Risks to Maximixe Deployment and CostEffectiveness," Renew. Energy, vol. 97, pp. 667, 2016.

[24] Z. Dobrotkova, K. Surana, and P. Audinet, "The Price of Solar Energy: Comparing Competitive Auctions for Utility-Scale Solar PV in Developing Countries," Energy Policy, vol. 118, pp. 133, 2018

[25] U. Gupta, "India’s Installed Solar Capacity hits 41,6 GW," PV Magazine India, 2021. https://www.pvmagazine.com/2021/03/02/indias-installes-solar- 
capacity-hits-41-6-gw/ (accessed Sep. 23, 2021).

[26] A. Singh, et al, "Design and Analysis of a SolarPowered Electric Vehicle Charging Station for Indian Cities," World Electr. Veh. J., vol. 12, no. 3, pp. 2, 2021.

[27] S. Modjo, "PLN Vs Energi Terbarukan: Peraturan Menteri ESDM Terkait Penggunaan Sistem Pembangkit Listrik Tenaga Surya Atap," J. Huk. Lingkung. Indones., vol. 6, no. 1, pp. 20, 2019.

[28] Paul J. Burke, et. Al, “Overcoming Barriers to Solar and Wind Energy Adoption in Two Asian Giants: India and Indonesia," Energy Policy, vol. 132, pp. 1216-1228, 2019.

[29] E. Hamdi, "Berpacu Menuju 23\% Energi Terbarukan,” 2020. Institute for Energy Economics anf Financial Analysis (IEEFA).

[30] A. S. Bose and S. Sarkar, "India's E-Reverse Auctions (2017-2018) for Allocating Renewable Energy Capacity: An Evaluation," Renew. Sustain. Energy Rev., vol. 112, pp. 762-774, 2019.

[31] P. Simamora, M. Gabriella, and J. Christian,
"Mekanisme Lelang Terbalik (Reverse Auction) dalam Penurunan Biaya Pembangkitan Pembangkit Listrik Tenaga Surya (PLTS) Skala Besar,” 2019. Institute for Essential Services Reform.

[32] Solar Energy Industries Association, "Reverse Auction Mechanism," 2021 https://www.seia.org/initiatives/reverse-auctionmechanism (accessed Sep. 23, 2021).

[33] M. Z. Aulia, "Hukum Pembangunan dari Mochtar Kusumaatmadja: Mengarahkan Pembangunan atau Mengabdi Pada Pembangunan?," J. Undang, vol. 1, no. 2, pp. 370-371, 2018.

[34] M. Kusumaatmadja, Konsep-Konsep Hukum dalam Pembangunan. Bandung: PT Alumni, 2012.

[35] D. Roberts, "Feed-in Tariffs for Renewable Power and The Role of Auctions: The Chinese \& Global Exprience," China Econ. J., vol. 13, no. 2, pp. 152, 2020.

[36] J. Donker and X. v. Tilburg, "Three Indonesian Solar-Powered Futures: Solar PV and Ambitious Climate Policy,” Bundestag: TNO Publisher, 2019. 